\title{
Effect of Different Chemicals Compounds upon the Surface of Heavy Crude Oil
}

\author{
T. Nagalakshmi, A. Sivasakthi
}

\begin{abstract}
Heavy crude oil is one of the unconventional crude oil which is difficult to recovery by conventional methods. High viscosity of heavy crude oil is reduced by the usage of steam in thermal recovery processes. Chemical flooding practices were fewer in heavy oil field compared to thermal flooding due to the low reactivity of chemicals on high dense crude oil. In this research article, different chemical compounds were tested on the heavy crude oil in both ambient and hot water conditions. The chemical compound prepared in the ambient temperature of water has no effect on heavy crude oil. On the contrary, heavy crude oil gave response to the chemicals made up of hot water. The chemical compounds namely surfactants, solvents and some salts happened to change the surface of heavy crude oil in turn influence the recovery rate. The analysis is useful for the testing and selecting of specific chemical compound which will react with heavy crude oil and improve the production.
\end{abstract}

Keywords: Chemical Flooding, Heavy Crude Oil, Solvents, Surfactants, Thermal Recovery and Viscosity

\section{INTRODUCTION}

Heavy crude oil has the characteristics of high density, viscosity, stickiness as their physical properties. The chemical characteristics of heavy crude oil are asphaltenes, resins, saturates and aromatics along with the high sulphur content and small amount of Nickel and Vanadium. Heavy crude oil is unconventional oil due to its difficulty in recovery and production processes. Table 1 . gives the physical properties of heavy crude oil namely ${ }^{\circ} \mathrm{API}$, density, viscosity ranges $[1,2]$.

Table 1. Physical properties of heavy crude oil [3]

\begin{tabular}{|c|c|c|c|}
\hline & ${ }^{\circ}$ API & Density & Viscosity \\
\hline Heavy crude oil & $10^{\circ}-22^{\circ}$ & $920-1000$ & $100-10000$ \\
\hline
\end{tabular}

Heavy crude oil recovery becomes tough due to its high viscosity and adhesiveness. In most of the petroleum companies, heavy crude oil is recovery by enhanced oil

Revised Manuscript Received on December 30, 2019.

* Correspondence Author

Dr. T. Nagalakshmi, Professor, Department of Petroleum Engineering, Academy of Maritime Education and Training (AMET), Chennai. Email: nagalakshmi.t@ametuniv.ac.in

A. Sivasakthi*, Assistant Professor, Department of Petroleum Engineering, Vels Institute of Science, Technology and Advanced Studies (VISTAS), Chennai. Email: asivasakthi.a@gmail.com

(C) The Authors. Published by Blue Eyes Intelligence Engineering and Sciences Publication (BEIESP). This is an open access article under the CC BY-NC-ND license (http://creativecommons.org/licenses/by-nc-nd/4.0/) recovery as their primary or secondary recovery processes. The main enhanced oil recovery used for the heavy oil recovery is thermal recovery which uses heat effect to reduce the viscosity of heavy crude oil and helps in production. The thermal recovery methods used in the heavy oil are classified as steam based In-situ combustion and hot water flooding. Steam based recovery are dived into steam injection, Cyclic Steam Stimulation (CSS) and Steam Assisted Gravity Drainage (SAGD) [3, 4].

A chemical recovery method of heavy crude oil is rarely carried out due to the chemical inefficiency and lack of bonding with the unreactive heavy oil. The different chemical recovery methods are surfactant flooding, polymer flooding and alkaline flooding. In surfactant flooding any suitable surfactant such as anionic, cationic or non-ionic is flooded in the reservoir, which helps to reduce the interfacial tension between the crude oil and rocks or crude oil and water for the production of crude oil [5, 6].

In polymer flooding, appropriate polymers namely polyarcylamides (PAM) and xanthan gum (biopolymer) is applied in the crude oil well in order to increase the viscosity of water and improve the sweep efficiency. Alkaline flooding is an effective flooding process where the reservoirs have acidic conditions and some of the alkali such as sodium hydroxide and sodium carbonates are used. Alkaline flooding is not advised for the carbonate reservoirs due to abundant calcium ion which leads to the precipitation of hydroxide present in sodium hydroxide [7, 8].

In this research article, heavy crude oil was subjected to different chemicals namely salts, acids, surfactants, aromatics and saturates. The investigation helps to observe the changes on the surface of the heavy crude oil by the selected chemicals.

\section{MATERIALS AND METHODS}

\section{A. Materials Required}

Heavy crude oil was collected from the Western part of the Indian oil field for the investigation purposes. The laboratory chemicals were selected mainly salts, surfactants, acids, aromatics and saturates.

Chosen chemicals were Sodium Bicarbonate, Sodium Hydroxide, Sodium Chloride, Sodium Carbonate, Sodium Lauryl Sulphate (SLS), Triton X-100, Potassium Dihydrogen Orthophosphate, Calcium Sulphate, Barium Sulphate, Polyethylene Glycol, Diethyl Ether, 2-Chloro Phenol, Formaldehyde, Benzoic Acid, Barium Chloride and Acetone. Table 2. gives the picked chemicals and their corresponding structure and formula. 
Table 2. Specifications of selected chemicals

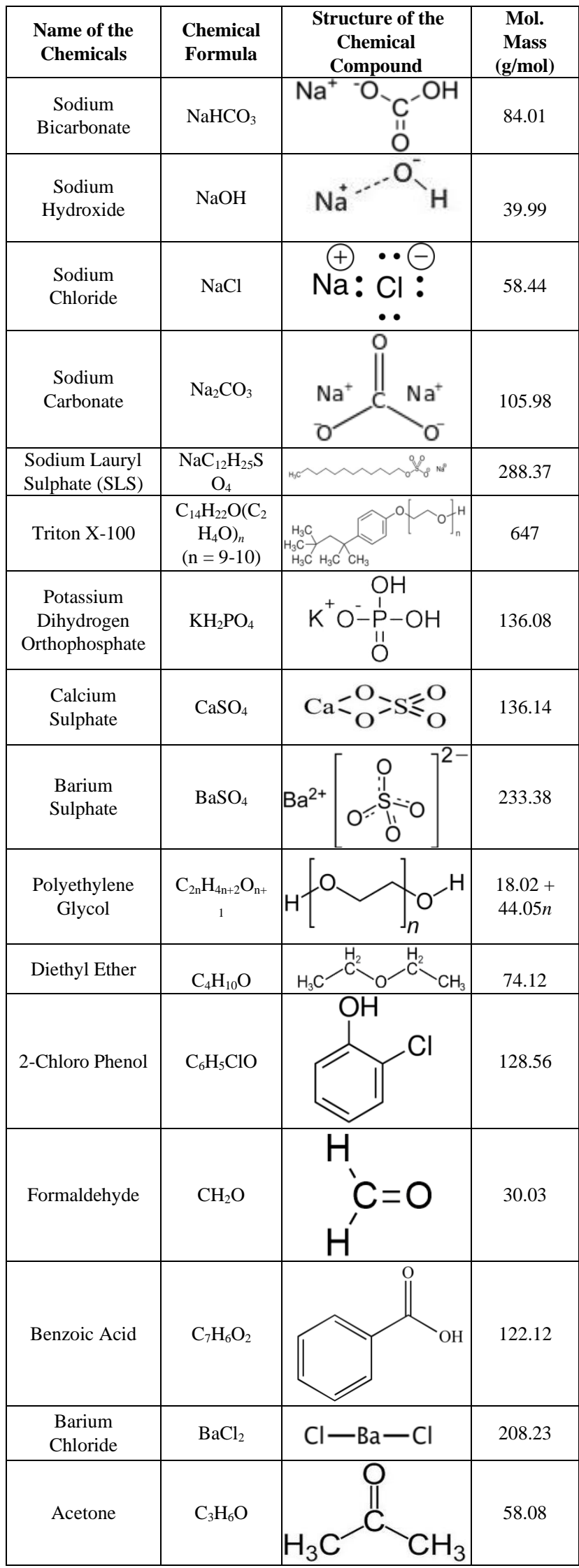

\section{B. Methodology}

Selected chemicals were taken in specific concentration and mixed with water. Twice the same concentrations of each chemical were taken and mixed in hot water as well as ambient water $\left(28{ }^{\circ} \mathrm{C}\right)$ separately. Same amount of heavy crude oil was used throughout the experimentation. The heavy oil was subjected to chemicals in both ambient water and hot water conditions.

\section{RESULTS AND DISCUSSION}

Heavy crude oil was investigated with the each chemical in ambient and hot conditions. Table 3 . shows positive and negative sign of the chemicals in ambient water on heavy crude oil reaction. The chemical concentration in the ambient temperature showed no sign of phase change, viscosity reduction or heavy oil separation.

Heavy crude oil recovery at $28{ }^{\circ} \mathrm{C}$ chemical solution becomes a difficult condition and there will be no change in the surface of the heavy crude oil. The experimentation with the ambient temperature helps to avoid the reservoir treatment of chemical compounds at $28{ }^{\circ} \mathrm{C}$ which has no effect on the heavy oil.

Now, the experiment was conducted with the chemicals in hot water individually on heavy crude oil. Table 4 . shows positive and negative sign of the chemicals in hot water on heavy crude oil reaction. Heavy crude oil found to show reaction on hot water with certain chemicals. The investigation results on heavy oil confirm that the selected surfactants, some salts and solvents can be applied in the crude oil recovery process.

Table 3. Effect of chemicals in ambient water $\left(28^{\circ} \mathrm{C}\right)$ on heavy crude oil

\begin{tabular}{|c|c|c|}
\hline $\begin{array}{l}\text { Name of the } \\
\text { Chemicals }\end{array}$ & $\begin{array}{c}\text { Density of } \\
\text { chemicals } \\
\left(\mathrm{g} / \mathrm{cm}^{3}\right)\end{array}$ & $\begin{array}{c}\text { Reaction of } \\
\text { Heavy crude oil } \\
\text { and chemical }\end{array}$ \\
\hline Sodium Bicarbonate & 2.100 & - \\
\hline Sodium Hydroxide & 2.13 & - \\
\hline Sodium Chloride & 2.16 & - \\
\hline Sodium Carbonate & 2.22 & - \\
\hline $\begin{array}{l}\text { Sodium Lauryl Sulphate } \\
\text { (SLS) }\end{array}$ & 1.05 & - \\
\hline Triton $\mathrm{X}-100$ & 1.07 & 一 \\
\hline $\begin{array}{c}\text { Potassium Dihydrogen } \\
\text { Orthophosphate }\end{array}$ & 2.34 & - \\
\hline Calcium Sulphate & 2.32 & - \\
\hline Barium Sulphate & 4.5 & - \\
\hline Polyethylene Glycol & 1.126 & - \\
\hline Diethyl Ether & 0.713 & 一 \\
\hline 2-Chloro Phenol & 1.26 & - \\
\hline Formaldehyde & 0.815 & - \\
\hline Benzoic Acid & 1.27 & - \\
\hline Barium Chloride & 3.86 & 一 \\
\hline Acetone & 0.784 & 一 \\
\hline
\end{tabular}

- means no reaction between chemicals and heavy crude oil

$\dagger$ means there is a reaction between chemicals and heavy crude oil

The selected surfactant reacts with heavy crude oil in the hot water conditions in other to reduce the surface tension and the particles tried to form an emulsion with the crude oil. Most of the solvents chosen were capable of reacting with heavy crude oil and many researches are being carried out in the field of heavy oil recovery by the injection of hot water with solvent. The influence of solvents and surfactants on the crude oil were fair than the salts and alkaline solutions. 
Table 4. Effect of chemicals in hot water $\left(80^{\circ} \mathrm{C}\right)$ on heavy crude oil

\begin{tabular}{|c|c|c|c|}
\hline $\begin{array}{l}\text { Name of the } \\
\text { Chemicals }\end{array}$ & $\begin{array}{l}\text { Density of } \\
\text { chemicals } \\
\left(\mathrm{g} / \mathrm{cm}^{3}\right)\end{array}$ & $\begin{array}{l}\text { Reaction } \\
\text { of Heavy } \\
\text { crude oil } \\
\text { and } \\
\text { chemical }\end{array}$ & Observations \\
\hline $\begin{array}{c}\text { Sodium } \\
\text { Bicarbonate }\end{array}$ & 2.100 & - & $\begin{array}{c}\text { Solution completely } \\
\text { mixed with water but } \\
\text { no reaction with the } \\
\text { heavy oil }\end{array}$ \\
\hline $\begin{array}{l}\text { Sodium } \\
\text { Hydroxide }\end{array}$ & 2.13 & - & $\begin{array}{l}\text { No reaction between } \\
\mathrm{NaOH} \text { and heavy oil }\end{array}$ \\
\hline Sodium Chloride & 2.16 & - & $\begin{array}{l}\text { Deposition of salt on } \\
\text { the surface of heavy } \\
\text { oil }\end{array}$ \\
\hline $\begin{array}{l}\text { Sodium } \\
\text { Carbonate }\end{array}$ & 2.22 & - & $\begin{array}{l}\text { No reaction between } \\
\mathrm{NaOH} \text { and heavy oil }\end{array}$ \\
\hline $\begin{array}{l}\text { Sodium Lauryl } \\
\text { Sulphate (SLS) }\end{array}$ & 1.05 & $\dagger$ & $\begin{array}{l}\text { A few particles of } \\
\text { heavy oil responded } \\
\text { to the SLS }\end{array}$ \\
\hline Triton X-100 & 1.07 & $\dagger$ & $\begin{array}{l}\text { A few particles of } \\
\text { heavy oil responded } \\
\text { to the Triton X-100 }\end{array}$ \\
\hline $\begin{array}{c}\text { Potassium } \\
\text { Dihydrogen } \\
\text { Orthophosphate } \\
\end{array}$ & 2.34 & $\dagger$ & $\begin{array}{c}\text { A few particles of } \\
\text { heavy oil responded } \\
\text { to the } \mathrm{KH}_{2} \mathrm{PO}_{4}\end{array}$ \\
\hline Calcium Sulphate & 2.32 & - & $\begin{array}{c}\text { Calcium sulphate } \\
\text { compounds got } \\
\text { separated on addition } \\
\text { of hot water }\end{array}$ \\
\hline Barium Sulphate & 4.5 & - & $\begin{array}{l}\text { Deposition of salt on } \\
\text { the surface of heavy } \\
\text { oil }\end{array}$ \\
\hline $\begin{array}{l}\text { Polyethylene } \\
\text { Glycol }\end{array}$ & 1.126 & $\dagger$ & $\begin{array}{c}\text { A few particles of } \\
\text { heavy oil responded } \\
\text { to the Polyethylene } \\
\text { Glycol }\end{array}$ \\
\hline Diethyl Ether & 0.713 & $\dagger$ & $\begin{array}{l}\text { A few particles of } \\
\text { heavy oil responded } \\
\text { to the Diethyl Ether }\end{array}$ \\
\hline 2-Chloro Phenol & 1.26 & $\dagger$ & $\begin{array}{c}\text { A few particles of } \\
\text { heavy oil responded } \\
\text { to the } 2 \text {-Chloro } \\
\text { Phenol }\end{array}$ \\
\hline Formaldehyde & 0.815 & $\dagger$ & $\begin{array}{l}\text { A few particles of } \\
\text { heavy oil responded } \\
\text { to the Formaldehyde }\end{array}$ \\
\hline Benzoic Acid & 1.27 & - & $\begin{array}{c}\text { Benzoic Acid } \\
\text { compounds got } \\
\text { separated on addition } \\
\text { of hot water }\end{array}$ \\
\hline Barium Chloride & 3.86 & - & $\begin{array}{c}\text { No reaction between } \\
\text { Barium Chloride and } \\
\text { heavy oil }\end{array}$ \\
\hline Acetone & 0.784 & - & $\begin{array}{c}\text { No reaction between } \\
\text { Acetone and heavy } \\
\text { oil }\end{array}$ \\
\hline
\end{tabular}

- means no reaction between chemicals and heavy crude oil

† means there a reaction between chemicals and heavy crude oil

\section{CONCLUSION}

Heavy crude oil is a high thick-viscous crude oil and recovery rate can be increased by the use of thermal enhanced oil recovery method. Several thermal methods apply heat effect through steam which reduces the viscosity of crude oil. The steam applied into the reservoir was generated either on the surface or sub-surface. The chemical enhanced oil recovery methods are used only in particular regions due to its slight reactivity with the heavy crude oil.

The investigation was carried out to give impression of the selected chemicals reaction with the heavy crude oil. The results of the experiments helps to find that the chemicals mixed with ambient water have no effect in the heavy crude oil. On the other hand, the same chemicals in hot water showed a positive response on the same amount of heavy crude oil. The selected chemicals particularly surfactants, solvents and some salts observed to react with heavy crude oil while other chemicals has no reaction with crude oil or separated in the preparations with hot water. The study assists in chemical flooding processes of heavy crude oil.

\section{REFERENCES}

1. Richard F. Meyer, et. al., "Heavy oil and natural bitumen resources in geological basins of the world," U.S.A. Geological Survey (USGS), Open File-Report 2001-1084, 2007.

2. Rick Penney, Schlumberger, "Heavy Oil Developments in the Middle East," Schlumberger, Heavy Oil, October 2010.

3. Santos, R.G., et. al., "An Overview of Heavy Oil Properties and Its Recovery and Transportation Methods," Brazilian Journal of Chemical Engineering, ISSN 0104-6632, Vol. 31, No. 03, pp. 571-590, July-September 2014.

4. James J. Sheng, "Status of surfactant EOR technology," Petroleum 1 (2015) 97-105.

5. Richard J. Farn, "Chemistry and Technology of Surfactants," Blackwell Publishing Ltd. 2006.

6. Sara Bülow Sandersen, "Enhanced Oil Recovery with Surfactant Flooding," Ph.D. -Thesis. 2012.

7. H. Yousefvand and A. Jafari (2015)," Enhanced Oil Recovery Using Polymer/nano silica," 5th International Biennial Conference on Ultrafine Grained and Nanostructured Materials, UFGNSM15.

8. Kun Sang Lee (2011), "Efficiency of Horizontal and Vertical Well Patterns on the Performance of Micellar-polymer Flooding," 2012 International Conference on Future Energy, Environment, and Materials.

\section{AUTHORS PROFILE}

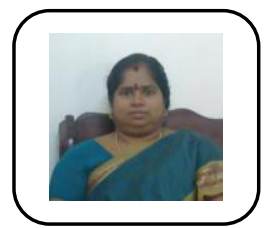

Dr.T.Nagalakshmi currently working as a Professor in the department of Petroleum Engineering in AMET UNIVERSITY for the past 8 years and earlier as Assistant Professor in the department of Petroleum Engineering in Rajiv Gandhi College of Engineering Affiliated to Anna University Chennai \& Accredited to AICTE New Delhi. I have experience as Project Associate in the division of soil mechanics where I underwent research in laterites and three years of experience as junior research fellow in the DST Project in the Anna University. Guiding Ph.D Full Time \& Part Time Research scholars, guiding B.E \& M.E Petroleum Engineering students for their final year projects. Written research articles in the field of Petroleum, geology and chemical engineering. Member in AAPG Women's Forum and in SEG .Life time member in GIAN ( Global Initiative of Academic Networks) and have attended FDP "Flow assurance in Petroleum Industry" in IIT Chennai. Member in the Academic Council of AMET University and member of Board of Studies in Petroleum Engineering Department.

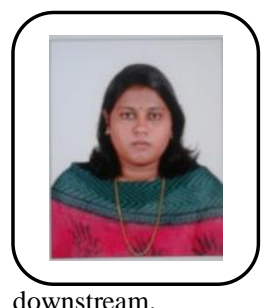

A.Sivasakthi currently working as an Assiatant Professor in the Department of Petroleum Engineering, Vels Institute of Science, Technology and Advanced Studies (VISTAS), Chennai. I am also pursuing Ph.D. in the department of Petroleum Engineering in Academy of Maritime Education and Training (AMET), Chennai. I have published research article in the area of upstream and

downstream. 